\title{
Theological Unity and Mitigation Approaches of Global Civilization Conflicts: Manhäj al-Turath Wa al-Tajdid
}

\author{
Mif Rohim Noyo Sarkun \\ Universitas Hasyim Asy’ari, Tebuireng, 61471, East Java, Indonesia \\ \{mifsyarkun@gmail.com\}
}

\begin{abstract}
All people in the worldwide have experienced civilization conflicts during a century. Most of the conflicts raised are due to the different paradigm in understanding ideology and political preference that has consequently caused around 160 million people killed. The history of human civilization is indeed reported with its social conflicts and clash of civilization, and these have become an inspirational thinking to construct of manhāj al turath wa al-tajdid in order to resolve the potential clashes of human civilization. In the $3^{\text {rd }}$ millennium, people are expected to become more religious to resolve the conflicts. The fundamental ontology of manhajj al turath wa al-tajdid is to establish wealth and peace society through philosophical approach of religion doctrines. All religions admit that human being is created by God through Adam and Eve (abu al-basyar umul al-basyar). In meantime, the theological ideology is also identical that is "There is no god but God". This paradigm is thought as the most moderate, appropriate and peaceful approach that is enable to accommodate all interests that will bring a harmonious life among societies.
\end{abstract}

Keywords: Theology, Unity, Philosophy, Conflicts, Mitigation

\section{Introduction}

The 20th century could be considered as the "starting point" century in human civilization development which was marked by the amazingly growing technology. In this century, the Information and Communication technology was so rapidly developed, thus led to the ease of communication and news spreading throughout the world [1]. On the other side, the developed technology apparently implied negative consequences to the humanity which indirectly imparting the consecutive crisis of global finance system, political conflicts and paradoxical clash of civilizations [2]. It was reported about 160 million people were killed during the 20th century due to the interstate wars and human right violations. All leaders in the worldwide struggled to find appropriate and effective solution to resolve the conflicts. Unfortunately, diplomatic negotiation were ineffective to resolve the conflicts, even further, military responses antagonizing and inflaming an already volatile population, retaliation leading to worse condition. 
It is noted that the global conflicts were initiated by the September 11th 2001 incident on the WTC towers in New York and the Pentagon's Military Headquarters of the United States (U.S.). Since that day, the U.S. government had spread the stigma that Muslims were terrorists and terrorists were Muslims. This provocations were quickly spread throughout the world aiming to obtain the international supports, enduring domestic pressures as the government was not be able to survive their pax-Americana and their laissez-faire capitalism ideology. Consequently, human rights violations to the Muslim communities in the U.S. were reported to had increased significantly, even now it has raised the Islamophobia movements in the U.S. and European countries. Further, the invasion of the U.S. army to the Middle East countries has caused millions of Muslim people including women and children killed, imparting worse global conflicts. How can we resolve this complex conflict since diplomatic and military responses were reportedly failed? In this article, we present an alternative approach based on the philosophy of religion on mitigation of potential global conflicts. The concept emphasizes on deity value, equality and humanity which are the main essence of the Unity of Theology. This paradigm is thought as the most moderate, appropriate and peaceful approach that is enable to accommodate all interests that will bring a harmonious life among societies.

In addition, it is also important to understand the meaning of Monotheistic concepts and theology of the great Samawat religions (Jewish, Christian, Islam). Particularly, every Muslim is responsible to understand the Qur'ān to demonstrate that Islam is a peacefully religion that will spread the love and peace throughout the world.

\section{Result and Discussion}

\subsection{Theological Unity as a Symbol for World Peace}

Jewish, Christian and Islam have many things in common, which include their similar of ideological concept that is "There is no god but God", and historical background in which Ibrahimic religions and their genetic disposition that the Prophet Adam was the first man and the progenitor of human beings. The Prophet Ibrahim essentially ancested to the appearance of Judaism (Mose), Christianity (Isa) and Islam (Muhammad), respectively. Ibrahim's marriage with Siti Hajar gave birth to Prophet Ismail, whose the lineage brought forth to the Prophet Muhammad and the Arabian nations, whereas the Ibrahim's marriage with Siti Sarah bore Prophet Isaac, Prohet Ishaq, and then to Prophet Yaakob. The lineage of Prophet Yusuf to Prophet Mose practiced Judaism, whereas the Prophet Isa brought Christianity. The Prophet Mose, Prophet Isa and Prophet Muhammad come from the lineage of Prophet Ibrahim. Judaism, Christianity and Islam are also identical in respect to the Rububiyyah and Uluhiyyah theology.

The main difference among these three religions is in the aspect of Shari'ah, because Shari'âh is the rule of law that is relevance to the time and place. Ritual worships, like prayer is considerably included in the context of Shari'âh, but not in the theological context [3]. During the Prophet Adam's time, marriage was allowed to be carried out with the siblings, while in the Prophet Mose's time one man was permitted to marry with one hundred of women, due to at that time many men were killed by the Pharoah. Hence, in the context of the Shari'āh, the learnings by the Prophet Adam, Prophet Ibrahim, Prophet Mose, Prophet Isa and Prophet Muhammad are mutually contiguous, in fact, most of the ushul al -fiqh scholars asserted that syar'un man qablana (Shari'âh of the Prophets and Apostles) as one of Islamic 
law sources, and the concept of theology is indeed indifferent that is "There is no god but God" [4].

After history takes its course, it then raises a clash of civilization, economy and political interests. Debate and arguments are occurred among the leaders and scholars concerning the theological aspects of Rububiyyah and Uluhiyyah and the concept of trinity as touted by Christians and Uzair as the son of God (Judaism). Arguments and quarrels among them even lead to the status of Abrahamic religion, in which the claim that the Prophet Ibrahim is the follower of their religion. Therefore, in this matter Allah has explained it in Q.S. 2: 105 that their claiming are lack of knowledge and merely based on their emotions [5].

The verse tells that the theological concept of Monotheism is the inspiration and regulation of the living as one race and nation globally. Every human has the same rights and liberties. There is no distinction of race, colour, sex, language, religion; God has even forbidden violations of imposing the doctrine and forcing people to convert to a particular religion. Besides, Islam does not differ between men with women, or Muslims and non-Muslims. When the transition was happening from the time of the Prophet to the companions tabi'in mujtahid, a genuine transformation occurred despite having the same reference for their understanding on Islam which was the masadir al-ahkam alaihi al-Muttafaq. (Qur'ān and Hadith), as a result from the drastic transformation of times, political prominence, geographic differences, ethnocentrism and other intellectual capacity. The inference of law triggered by the mujtahid initially, and then continuedly by Hijri to their followers from the third to the sixth century [6]. Both the manhāj al -Fikr and the inferences of the syar'iyyah law were felt containing conflicts against the international standardization policy, resulting more irrelevant ideology, anarchism and direct conflict of human rights violations. Therefore, the Muslim leader should do reinterpretation of religious ideological doctrine and theological doctrine.

\subsection{The World Civilization in the $1^{\text {st }}$ Millennium}

The development of Islamic history began in the middle of the $1^{\text {st }}$ millennium of the year of 610 when Islam was rised in Makkah, and three years later Islam spread throughout the Arabian lands; including in Medina. The Muslims had to face uncivilized Makkah pagan society (300-610), while they also had to deal with the two strong imperiums of the world. In the West they had to deal with The Roman empire led by Roman commander that was Arsaces XIV, while they face the Persian empire Nations in the East which had been at war for centuries since the time of Pompey Great, led by Kisra Parthia Persi. The war was caused by the competition of potential strategic and economic areas between Syria, Sicily, Armenia etc.. These two great civilizations are mentioned in the Qur'ān that the war was interchangeable in victory and defeat [7]. In 611-615 the Persians easily took over Eastern Rome, Syria and Palestine. In the year of 622 the Roman empire successfully defeated the Persian empire which coincided with the victory of the Muslims against the Pagans in the battle of Badr. In meantime, they also had to face the Greek philosophers like Plato, Aristotle, Pythagoras etc. that led to a clash between philosophical religion and science, in which the conservative Western religion was shackled by the church's exclusive doctrine concerning the relationship between human life and God where human beings as the passive creatures [8].

In this bawdy world, Islam came to bring the light of truth, the Prophet Muhammad with his monotheism that is "There is no god but Allah" after he successfully ruling the Arabic peninsula. His next political targets were to defeat both Roman imperium and Persians by laying on the principle meaning of the Uluhiyyāh monotheistic faith and the meaning of Jihād. In the time of Caliph Umar bin Khattab, Islam had a new strength in the midst of the 
competition between two strong Roman and Persi imperium. After defeating the Persians in the East and West Rome Nation, Islam community had a tremendous strength in economy and military to develop the Islamic civilization, they gathered the scattering people to embrace the religion of Allah. The presence of Islam eliminated the element of 'Asabiyyah (Fanatic to ethnic or racial) regionalism and tribalism, as there was no difference between the Arab tribes, Romans, Persians and others, that there was only compliance under the banner of Tawheed, "There is no god but God " [9].

Muslim members tremendously contribut to the world civilization. The biggest contribution is in the form of the theological aspects of religion: "There is no god but God and Muhammad is the messenger of God". This identity of theological concept unite people irrespective to race, ethnicity, geographic descendants. As result, Islam is readily accepted by all the nations in the world to upholding the amar nahi munkar. Besides it, Islam rules human life through Shari'āh law to show a clear direction toward the development of culture, hoping it will be inspiring this theological concepts can be accepted as the fundamental of civilization. Meanwhile, the Shari'āh indicates the direction of the development of Islamic civilization through faith and Islam [10].

There are two methodologies to explore the values of faith and Islam's reign in developing civilization, i.e. Manhāj al-hukmi, and Manhāj al-Ilmi. Manhāj al-hukmi, (methodology in law formulation) relating to the methodology of Islamic legal thinking which influences the development of a global mindset methodology until now. This methodology including the Inductive methodology of Imam Abu Hanifah with natural phenomenon to be reunited with the Qur'ānic text, and deductive methodology of Imam Syafi'i which making the Naskh as the inspirational text that should be implemented in the life. These methodologies are known as the Manhāj al ijtihad (ijtihād methodology) and Manhāj al-Fikr (thoughtful). Inductive methodology is sourced from the thoughts of Imam Abu Hanifah that is to find better judgment or the best solution to resolve the problems [11]. The Q.S. 39: 17-18 inspires the istihsan methodology. Accordingly, Madhhab Hanafi, Maliki and Hanbali agree to accept this verse as an evidence for the ijtihād methodology with Istihsan. While the Q.S. 4: 59 becomes the evidence of Imam Syafi'i and his analogical methodology. All the most legal scholars and jurisprudence accept the analogy as an ijtihād method.

Both ideas are to formulate the rules of law which relate to the life as one race and nation in all aspects such as economic, legal, politic, civilization, etc.. Law is derived according the methodology of al-hukm that is based on the principles of justice and charity. The istihsan methodology of Imam Abu Hanifah has been used as the fundamental of thinking and ijtihād [12]. Meanwhile, the Western law is equity (the concept of natural justice) by considering the public interest (public interest and the best solution), because the public interest is thought as the principle of Shari'āh legislation in order to find the best and fair solution. Mohammad Hashim Kamali stated that the Western legal concept based on justice, truth and the rights deviates from the rule of positive law when its implementation resulted injustice or an original law which is superior to other legal rules, giving way of settlement based on the principles of divine law [13].

The scientific Manhāj al-Ilmi Islamic methodology has encouraged the rise of many philosophical and Islamic scientists giving contribution to the world civilization [14]. Dr. Muhammad Hanafi listed 72 philosophist and scientists in his book entitled Ilmuan Islam where they used scientific methodologies. Ibn Sina used the Qur'ann as the source of knowledge which must be reconciled with nature that would later gave birth to technology. Muhammad Ibn Zakariya al - Razi asserted that nature as an element that must be met with the 
Qur'ān in determining the truth of science and technology. Both methodologies inspired the development of global Islamic legal thought methodologies.

\subsection{The Word Civilization in the $2^{\text {nd }}$ Millennium}

Many incidents occurred during the 2nd millennium, but the the most attracted incident was the victory of Church over the Muslims. The great Muslim political power was no longer unable to be defended against greater powers of the values of the Deity and Humanity. While, internal conflicts within Islam community also imparted to the fall of Islamic civilization glory after Islamic empire was taken over by the Christian. Christian crusade was launched by a group of Christian Europe against the Islamic countries for almost 200 years between 1097 to 1270 which ended with the fall of the Islamic empire. Church controlled the world, Muslims were under theological ideology, political and intellectual pressure.

The triumph of Church over the Islamic empire provided positive effects on the Western world in various aspects such as intellectual, social, economic, technological science and religious. Moreover, colonialism and imperialism movement launched by the West in the early 19th century led to the divided territories, in which the Dutch colonized Indonesia and Malaysia, the Indian was imperialized by the England, meanwhile the Iran became the bone of contention between the Soviet Union and France. Upon entering the $19^{\text {th }}$ century, World War I and World War II took place around the world. World War I was happening from July $28^{\text {th }}$ 1914 to November $11^{\text {th }} 1918$ between the allied countries including France, Britain and Russia, the countries of "central Powers" comprising of Germany, Austria, Hungary. Initially, the battle was won by Central Powers, but then the Germany was defeated due to the fatigue and internal constellation.

Upon entering the 1941, the World War (WW) II took place from September $11^{\text {th }} 1939$ to 1945 which involved many countries and more than 100 million people. This WW II evoked around 50-70 million people killed that is known as the most lethal conflict in history of human beings. During the War, Germany together with Italy formed an alliance to control most of Europe and invaded the Soviet Union which in turn raised open war. Further, the Japan joined with the Germany-Italy alliance invaded the United States and the European territory located in the Pacific Ocean and quickly ruled most of the Western Pacific. The invasion was ended when the Soviet Union successfully took back all of their territories from Germany, and even the Berlin was occupied by the U.S. In addition, the Japan was lost in the battle against the U.S.

Indeed, friendship of the two great nations of the U.S. and the Soviet Union was not long. Cold war between the both countries was arouse due to the competition in politic, military power and ideology which it then ended with the fall of Soviet Union, resulting the United States as a super power country. The presence of U.S. America as a super power country apparently did not bring a peaceful situation to the world. Emanuel Hantington stated that there will appear radical Islamic forces as rival to the U.S [15]. His forecasts come true, on September $11^{\text {th }} 2011$ the world was startled by the WTC bombing in New York and the Headquarters of U.S. Military in Pentagon. It turned out a speculation about the perpetrators of the bombing. The U.S. quickly used this momentum to launch a stigma that Islam are terrorists and terrorists are Islam. The propaganda "Islam is terrorist and America as the terrorist exterminator" was spread throughout the world with the aim to get international support. 


\subsection{Epistemology of Global Civilization in The 3rd Millennium}

In the 3rd millennium, the development of technology in human civilization is expected to be more dynamic and progressive. It will be manifested in space and time of human life, encouraging the Muslims to reveal the miracle of the Qur'ann which contains science and technology. Politically, the presence of three most powerful countries namely; the U.S. America and its Allies, the Soviet Eastern bloc countries, China, Korea and their allies, likewise that happened in the early 7th century where the Roman ruled the West, the Persian reigned the East and the Islam was then appeared as the third counterpart. It seems likely that the same situation will be appeared in near future since in the last of 20th century the U.S. America has appeared as a great country. Reflecting back to the history, it is envisaged that the Islam will appear as the third power counterpart. Therefore, Muslims must be able to formulate a framework of epistemology through theological concepts "There is no god but God" that is an identity and a consensus of many religious countries in the world, especially the Samawat religions that need to re-actualize the implementation of global human life.

In the clash of civilization that taking place in the 3rd millennium, Muslims will attain victory only if they are able to uphold the highly values of Deity and Knowledge (Science). Furthermore, monotheism concept taught by the Prophet Muhammad is known as the one factor enable to encourage the Muslim for the victory. This concept has imparted to the victory of Muslim during the 1st and 2nd millennium because of it is the spirit of unity of the Muslim to uphold the values of Deity and Humanity. The fall of Islamic empire however, was not due to the great power of Christian and Western world. It is noticeable that the fall of Islamic empire was as a consequence of crashing over to the highly values of Godhead and Humanity revelated by the God that have become convention of the Samawat religions. In order to encounter the movement, Muslims must go return to the doctrine of Deity and Humanity philosophy that is identity unite revolution. Abdurrahman Wahid asserted that the highly values of Deity and Humanity is identity as well as integrity of Islamic conception for Muslim's life to the enforcement of human dignity through efforts to achieve full autonomy for the individual over the community, upholding the rule of law, respect to human rights, strengthening (empowerment) of the future. It should be placed on cultural economic and strong politic, because those of principles are then concerned to be important in achieving a new paradigm of independence such as refusal of violations [16].

Although imperialism and colonialism are no longer existed nowadays, but the essence and effects are still felt and even more terrible. Formerly, imperialism and colonialism were occupation of strong countries over the weak countries to exploiting natural resources belong to the weak countries, as the Western countries did to the Muslim countries dividing the political regions. The recent colonialism and imperialism occur in all aspects of life including culture, economic, politic and religious culture. It is should be noted that the colonialism and imperialism in the past and present are same, even though their ways are different. Therefore, the Muslim must be able to reunite and to do universal revolution in creating internal balance in Islamic community (Sunnih and Syi'âh), to liberate themselves from the influence of other parties in order to remove the stigma of "superiority of the West over the East", and to fight against discrimination and human rights violations.

\subsection{Manhāj al-Turath Wa al-Tajdid as the Mitigation of Global Civilization Conflicts}

It has been noted that the history of human civilization during the $1^{\text {st }}$ and $2^{\text {nd }}$ millenniums is the inspirational basis to formulate the manhäj al turath wa al-tajdid in order to resolve the 
clashes of human civilization. In the $3^{\text {rd }}$ millennium, people are expected to use religious methods to resolve the conflicts alternative to war. Hence, the current millennium is so-called the "Century of Spiritualism".

The fundamental ontology of the manhäj al turath wa al-tajdid to establish wealth and peace society is through historical and philosophical approach of religion doctrines. All religions admit that human being is created by God through Adam and Eve (abu al-basyar umul al-basyar). In meantime, the theological ideology is also identical that is "There is no god but God", containing the concept of rububiyyah (God is the universe creator) and uluhiyyah (prayer only to the God). The difference among them is merely the utterance and the way to praying. Moreover, the three Samawat religions i.e. Jewish, Christian and Islam come from the religion of Hanifa Muslima by the Prophet Ibrahim. Although having difference in utterance but they are essentially identical, that is "There is no god but God", emphasizing the concept of peace and love. This theological concept is mithaqan ghalidzah (holy agreement) between the God and the Prophets (Adam, Ibrahim, Mose, Isa, and Muhammad), and it is clearly noted in the Qur'ān. The Islam admits Taurat and the Bible as the holy scriptures that give light and directly correlate with the Qur'ann. It is stated that the Jewish, Christian and Muslim as Ahl al-kitb (brotherhood in Ahl kitb) so We return to the Holy agreement "There is no god but God". Accordingly, the epistemology of the manhāj alistilahiyyah is introduced to realize the corresponding concept since the three religions have an identical fundamental ontology. This manhäj al-istilahiyyah methodology is thought as the proper methodology in comparison to al-thathurrufiyyah (radicalism and liberalism) to accommodate the unification of the three religions under the same of theological doctrine towards a peacefully world rahmatan lil 'alamin (axiology).

\section{Conclusion}

The September $11^{\text {th }} 2001$ bombing incident started the global conflicts in the 3rd millennium. Since that day, there is negative stigma spread throughout the wold that "Muslims are terrorists and terrorists are Muslims". As a consequence, human rights violations to the Muslim communities in the U.S. have increased significantly, even now it has raised Islamophobia movements in the U.S. and European countries. Moreover, the invasion of the U.S. army to the Middle East countries has caused millions of Muslim people including women and children killed, raising worse global conflicts. In order to prevent worse global conflicts, all leaders in the worldwide have been struggling to find appropriate and effective solutions to resolve the ongoing conflicts. Nonetheless, diplomatic negotiation and military responses are ineffective to resolve the conflicts.

The manhāj al turath wa al-tajdid is then constructed as an alternative way in global conflicts mitigation, that is essentially based on the doctrine of Unity of Theology. The fundamental ontology of the manhäj al turath wa al-tajdid to establish wealth and peace society is through historical and philosophical approach of religion doctrines. The epistemology of manhāj al-istilahiyyah is applied to realize the concept of manhāj al turath wa al-tajdid since the three religions have an identical fundamental ontology. This manhäj alistilahiyyah is thought as a proper methodology to accommodate the unification of the three religions under the same of theological doctrine towards a peacefully world rahmatan lil 'alamin (axiology). 


\section{Acknowledgment}

Financial supports from Universitas Hasyim Asy'ari and constructive comments from Dr. Faisal Amri Tanjung are greatly acknowledged.

\section{References}

[1] Shimogaki, Kazuo, Between Modernity and Postmodernity. Jakarta: Gramedia, 1988.

[2] National Commision of the United State of America, The Financial Crisis Inguiri Report. New York: U.S. Government Printing Office, 2011.

[3] Rauf, Feisal Abdul, Islam a Sacred Law: What Every Muslim Should Know About Syari'āh. Kuala Lumpur: YADIM, 2002.

[4] Al-Rahman, Abdu, Shari'āh The Islamic Law. London: First Published, 1984.

[5] Mahmasani, Al-Mahami Subhi, Falsafah al-Tashri' fi al-Islam. Damshiq: Daar alKashshaf, 1990.

[6] An-Na'im, Abdullahi Ahmaed, Dekonstruksi Syari'āh. Yogyakarta: LkiS, 2001.

[7] Yahya, Mahyudin, Tamadun Islam. Selangor: Fajar Bakti, 2003.

[8] Al-Afghani, Tahqiq Abu al-Wafa, Dar al-Ma'arif al-Nu'maniyyah. Beirut: Dar alKutub al-'Ilmiyyah, 1987.

[9] Al-Sarakhsi, Abi Bakr Muhammad b. Ahmad b. Abi Sahal, Usul al-Sarakhsi al-Wajiz fi Usul al-Fiqh. Baghdad: Jami'ah Baghdad, 1997.

[10] Hallaq, Wael B., A History of Islamic Legal Theories: An Introduction to Sunni Ushul al-Fiqh. Cambridge: Cambridge University Press, 1997.

[11] Al-Nasrati, Hamzah, Kitab Ushul al-Fqh Madhzb Hanafi, Madhhab Syafi'i, Madzhab Maliki and Madhhab Hanbali. Selangor: Fajar Bakti, 1998.

[12] Kamali, Mohammad Hashim, Principles of Islamic Jurisprudence (Istihsan, or Equity in Islam Law). Cambridge: Cambridge University Press, 1991.

[13] Hanafi, Muhammad, Ilmuan Islam. Kuala Lumpur: Seribu Dinar, 2010.

[14] Awang, Ramli, Modul Pengajaran Sains. Johor Bahru: Fakulti Tamadun Islam UTM, 2011.

[15] Huntington, Samuel P., The Clash of Civilization. Johor Bahru: UTM Press, 2010.

[16] Syarkun, Mif Rohim N., Konflik Pemikiran Hanafi dan Syafi'i. Kuala Lumpur: Universiti Malaya Press, 2008. 